Tranhsfer

\section{A Review of Certified Nursery Personnel Programs in the United States}

\author{
Michael A. Schnelle ${ }^{1}$ and Janet C. Cole ${ }^{1}$
}

Additional index words. education, garden centers

Summary. Nursery personnel certification programs are designed to advance professionalism throughout the nursery and garden center industry. Certified nursery personnel may be perceived more favorably by their employers, peers, and, most important, by the public they serve. Certification programs currently are conducted in 39 states. Many state nursery or related organizations also offer landscape certification programs; however, such programs are not addressed here.

Purpose. Many state nursery associations in the United States have developed a system of training, testing, and certifying nursery personnel. The purpose of certification is to recognize and upgrade the image of certified individuals. Certification indicates that a person has a higher level of horticultural knowledge and related practices than noncertified personnel. Programs of professional certification are endorsed by most state nursery associations, but are not enforceable by the state s nursery industry or its department of agriculture. The plurality of benefits to the individuals involved and the industry, however, provide strong incentives to become certified. Most states refer to the individual as either a certified or accredited nurseryman or certified nursery professional. However, some states designate titles, such as the Indiana Accredited Plantsman or North Carolina Plantsman.

Certification benefits. Nursery certification programs benefit the employee, employer, and the customer. Benefits to the employee include 1 ) employer recognition of moti-

$\overline{\text { Department of Horticulture and Landscape Architecture, Oklahoma State University, }}$ Stillwater, OK 74078

${ }^{1}$ Assistant Professor. vated employees, thus improving the employee s image and status in the company; 2 ) fellow employees recognize certified individuals as experts on a range of horticultural topics; 3) national recognition for newly certified individuals as their names are published in national nursery trade magazines; and 4) possible monetary rewards or promotion.

Benefits to the employer include 1 ) certified individuals possess the horticultural knowledge needed to work directly with consumers; 2) certified nursery personnel will usually seek advancement, and thus are productive employees; and 3) employers may advertise that employees are certified. This advertisement may create a marketing advantage.

Benefits to the consumer are evident in customer satisfaction derived from dealing with certified individuals as opposed to noncertified sales people.

Eligibility. Most nursery organizations require 1 to 2 years of work experience prior to certification; in some states college credits may substitute partially for work experience. Most states make no distinction among full- or part-time employees nor those who have only recently recentered the nursery industry. The main criterion for eligibility is a minimum number of hours in a nursery operation that is recognized by its state department of agriculture. Work experience, when required, ranges from 90 days to 3 years. One to 2 years of fill-time attendance in a post-high school institution (horticultural curriculum) is generally equivalent to one-half of the total work experience required. In some states, such as Arkansas, New Mexico, and Pennsylvania, college education may be considered in lieu of on-the-job experience. Several of the New England states have the highest work experience requirements of 3 to 4 years. Most of these states, however, lower the requirement when at least 1 year of college credit has been completed. In 24 of the 39 states, practical work experience is required for eligibility regardless of college hours accrued, including an earned horticulture baccalaureate degree. Most states require verification of work experience from the employer of the individual seeking certification before or soon after the examination is taken. In some states, the individual must have gained experience from an employer who is a member in good standing with the state s nursery organization. In most states, out-of-state nursery employment is recognized at least in part towards the work experience requirement. Prior out-of-state certification, however, is not recognized by most state nursery organizations.

Reciprocal certification agreements exist among some states, including Virginia with North Carolina and South Carolina, and Washington with Oregon. Washington and Oregon co-sponsor a manual that is used by both states. Idaho and Montana use the manual and program designed by the Idaho Nursery Assn. Montana pays the Idaho Nursery Assn. for all of the rights and privileges an Idaho Certified Nurseryman obtains. In other states, nonmembers of the state nursery association are not allowed to proceed with certification. Some state certification committees do not require a minimum number of work hours for the individuals who are owners or officers of a nursery firm. Certification includes a code of ethics or contract that varies widely in content among states. Some states reserve the right to request individuals that recertify to sign again the code of ethics statement.

Certification manual. All states offer a certification manual as the primary educational material for preparation 
Table 1. Typical topics included in a certified nursery personnel manual.

Instructions, plant list, and sample questions

The nursery industry

Plant parts, functions, growth and development

Introduction to nomenclature

Landscape plant materials

Plant hardiness zones

Interior plants

Fruit and nut trees

Vegetables and herbs

Annuals, perennials, and bulbs

Poisonous plants

Product display marketing

Outdoor container gardening

Landscape design

Xeriscaping

Landscape construction

Landscape contracting

Turfgrasses and their management

Weeds and weed control

Mulches

Soils

Plant nutrition

Plant propagation

Pruning

Plant pests and diseases

Applying pesticides correctly

Diagnostic key to plant problems

Planting procedures

Landscape crew efficiency and relationships

Maintenance of the newly installed landscape

Nursery and garden center maintenance

Receiving commercial shipments

Handling and overwintering nursery stock

Professionalism in the nursery industry

Selected laws and regulations

Nursery publications

Mathematical formulas and conversions

Grades and standards

in becoming certified. Certification study manuals vary widely in length, depth, and number of topics addressed. Manuals may discuss topics beyond those related to ornamental horticulture, such as fruits, vegetables, and herbs. Similarly, testing generally covers all topics that could be encountered in a retail nursery.

Certification manuals usually are written or edited by a committee of the state association. In most states, industry leaders are selected to author chapters based on the topics in which they have expertise. Varying amounts of assistance are provided by land-grant university professors of horticulture. In other states, such as South Carolina, the state extension specialists are the principal editors and authors and may also be involved in writing the tests. Universities often provide supplemental literature in the form of fact sheets, pesticide updates, etc. A typical table of contents from a training manual is shown in Table 1. Some organizations relay to the candidates for certification that what is not covered in the examination will be acquired from practical experience. This is part of the rationale behind many state organizations not waiving the practical experience requirement.
In addition to the study manual, 31 of the 39 states offer short courses or study sessions to aid individuals in preparation for the examination. These may be offered during annual conferences or other meetings related to the association membership. They may be offered through regional technical colleges as well. Some states, such as Arizona, offer extensive preparation in addition to the manual (3. 5-h lectures, once a week for 4 weeks before the test), while Connecticut has initiated a 13-week program of 90-min lectures once a. week before the examination. In place of intensive personalized training, some states substitute additional study materials such as slide sets, videotapes, or sample examinations to complement the manual.

Examination. Testing methods vary widely among state associations, with some administering relatively short examinations and others giving multiple-part tests with an average of $4 \mathrm{~h}$ allowed for completion. In most states, the examination is divided into three parts: 1 ) general information, 2) woody plant identification, and 3) a hypothetical landscape design.

Most general information tests are prepared directly from a manual provided by the state s nursery association. Nearly all of these tests include true/false and multiple choice questions, with few or no essay questions. Plant identification consists of visual recognition of several commonly used landscape plants to be identified by their scientific and common names, or selection of the species that best fits the written descriptions. In states such as Arizona, both types of identification examinations are administered. Last, a landscape plan must be prepared according to selected criteria of that association. This may include drawing a plan to scale, complete with a legend. Delaware requires, in addition to the general examination, that all candidates pass at least one of six specialty examinations that build upon the general examination. The individual is then recognized as having expertise in that specialty. This program of obtaining a specialty is mandatory, and differs from advanced certification programs in other states. Advanced certification programs are optional once the standard examination is passed and standard certification is awarded. Some state nursery organizations have identified a need for advanced certification. California, Texas, Maryland, Michigan, Indiana, Delaware, and Georgia all offer such programs. California offers specialty programs such as irrigation, turfgrass management, and insects, diseases, and weeds. The advanced personnel are recognized by a separate certificate for each examination passed. The remaining states offer advanced training, all of which usually is distinguished from the basic certification program by at least a higher acceptable minimum score and other means of recognizing such individuals from the normal training offered by the state.

All states require a minimum score for each part of the examination or for the average of all test sections. Required scores for most states range from $60 \%$ to 9 O . Scores normally are not adjusted relative to other students performance (curve not used). When multiple-part tests are conducted, normally a minimum score must be achieved in each section rather than an overall average. This prevents an individual from passing the examination without a working knowledge of any given subject area. Most state organizations require the student to only retake failed sections; however, some states expect the entire test to be retaken if any section is not passed. 
Alabama Nurserymen s Assn.
P.O. Box 9

Auburn, AL 36831

phone 205/821-5148

fax 205/821-5148

Arizona Nursery Assn.

1430 W. Broadway, Suite A-125

Temp., AZ 85282

phone 602/966-1610

fax 602/966-0923

Arkansas Nurserymen s Assn

P.O. Box 250763

Little Rock, AR 72225

phone 501/225-0029

California Assn. of Nurserymen 4620 Northgate Blvd., Suite 155 Sacramento, CA 95834

phone 916/567-0200

fax 916/567-0505

Colorado Nurserymen s Assn

9101 E. Kenyon Avenue, Suite 3000

Denver, CO 80237

phone 303/770-3343

fax 303/770-1812

Connecticut Nurserymen s Assn

24 West Road, Suite \#53

Vernon, CT 06066

phone 203/872-2095

fax 203/872-6596

Delaware Assn. of Nurserymen

331 Merrill Way

Smyrna, DE 19977

302/653-1021

Florida Nurserymen and Grower s Assn.

5401 Kirkman Rd., Suite 650

Orlando, FL 32819

phone $407 / 345-8137$

fax $407 / 351-2610$

Georgia Nurserymen s Assn.

190 Spring Tree Rd.

Athens, GA 30605-2418

phone 706/548-1257

Illinois Nurserymen s Assn.

1717 south Fifth St.

Springfield, IL 67203

phone 217/525-6222

fax 217/525-6257

Indiana Assn. of Nurserymen, Inc.

716 Elberta Dr.

Vincennes, IN 47591

phone $812 / 882-8284$

fax $812 / 885-4266$

Iowa Nurserymen s Assn.

7261 N.W. 21st St.

Ankeny, IA 50021

phone 515/289-1790

Kansas Assn. of Nurserymen

411 Poplar

Wamego, KS 66547

phone913/494-2418

fax 913/452-2066

Kentucky Nurserymen s Assn

701 Baxter Ave.

Louisville, KY 40204

phone 502/451-5630

fax 502/429-6205
Louisiana Assn. of Nurserymen, Inc.

Burden Research Plantation

4560 Essen Lane

Baton Rouge, LA 70809

phone 504/766-3471

fax 504/766-3664

Maine Nurserymen s Assn.

PST/SMTC

South Portland, ME 04106

phone 207/799-7303

fax 207/767-2731

Maryland Nurserymen s Assn.

P.O. Box 432

Perry Hall, MD 21128

phone 410/256-1799

fax 410/256-2208

Massachusetts Nurserymen s Assn.

P.O. Box 706

Leominster, MA 01453

phone 508/534-1775

fax 508/534-1777

Michigan Nursery and Landscape Assn.

819 North Washington Ave., Suite 2

Lansing, MI 48906

phone $517 / 487-1282$

fax 517/487-0969

Minnesota Nursery and Landscape Assn.

P.O. Box 130307

St. Paul, MN 55113

phone 612/633-4987

fax 612/633-4986

Mississippi Nurserymen s Assn., Inc.

P.O. Box 5385

Mississippi State Univ.

Mississippi State, MS 39762

phone 601/325-3935

fax $601 / 325-8379$

Missouri Assn. of Nurserymen

Route 1, Box 175

Clarksdale, MO 064430

phone 816/369-2005

Montana Assn. of Nurserymen

P.O. Box 1871

Bozeman, MT 59771

phone 406/586-6042

New Jersey Nursery and Landscape Assn., Inc. 65 South Main St.

Building A, Suite 3

Pennington, NJ 08534

phone 609/737-0890

fax 609/737-7794

New Mexico Assn. of Nursery Industries

3820 Midway Place N.E.

Albuquerque, NM 87109

phone 505/345-7799

fax 505/345-8989

New York State Nursery/Landscape Assn.

P.O. Box 657

Baldwinsville, NY 13027

phone 315/638-8589

fax $315 / 638-8569$

North Carolina Assn. of Nurserymen

P.O. Box 400

Krightdale, NC 27545

phone 919/266-3322

fax 919/266-2137
Ohio Nurserymen s Assn., Inc.

2021 E. Dublin Granville Rd., Suite 185

Columbus, $\mathrm{OH} 43229$

phone 614/431-2452

fax $614 / 431-8032$

Oklahoma State Nurserymen sAssn.

400 North Portland

Oklahoma City, OK 73107

phone 405/942-5276

fax $405 / 942-5276$

Oregon Assn. of Nurserymen

2780 South East Harrison, Suite 102

Milwaukie, OR 97222

phone 503/653-8733

fax 503/653-1528

Pennsylvania Nurserymen s Assn.

1924 North Second St.

Harrisburg, PA 17102

phone $717 / 238-1673$

fax $717 / 238-1675$

Rhode Island Nurserymen s Assn.

64 Bittersweet Dr.

Seekonk, MA 02771

phone 508/761-9260

fax 508/761-9620

South Carolina Nurserymen s Assn.

809 Sunset Dr.

Greenwood, SC 29646

phone $803 / 223-7278$

fax $803 / 223-5785$

Tennessee Nurserymen s Assn., Inc.

P.O. Box 57

McMinnville, TN 37110

phone 615/473-3951

fax $615 / 473-588$

Texas Assn. of Nurserymen

7730 South IH-35

Austin, TX 78745

phone 512/280-5182

fax 512/280-3012

Utah Assn. of Nurserymen

3500 South 900 East

Salt Lake City, UT 84106

phone $801 / 487-4131$

fax 801/487-2030

Vermont Plantsmens Assn.

P.O. Box 1433

Blush Hill Rd.

Waterbury, VT 05676

phone 802/244-7048

Virginia Nurserymen s Assn.

383 Coal Hollow Rd.

Christiansburg, VA 24073

phone $703 / 382-0943$

fax $703 / 382-2716$

Washington State Nursery and Landscape Assn., Inc.

P.O. Box 670

Sumner, WA 98022

phone 206/863-4482

fax 206/863-6723 
Table 3. A comparison of nursery personnel certification standards across the United States.

\begin{tabular}{|c|c|c|c|c|c|c|}
\hline State & $\begin{array}{c}\text { Eligibility } \\
\text { requirements }\end{array}$ & $\begin{array}{l}\text { Study materials } \\
\text { and support }\end{array}$ & $\begin{array}{l}\text { Examination } \\
\text { structure }\end{array}$ & $\begin{array}{c}\text { Minimum } \\
\text { score (\%) }\end{array}$ & $\begin{array}{c}\text { Administering } \\
\text { institution }\end{array}$ & $\begin{array}{c}\text { Recertification } \\
\text { requirements }\end{array}$ \\
\hline Alabama & 1 year $^{2}$ & Manual, classes & General ID & $70^{y}$ & ANA & 5 years $^{\mathrm{x}}$ \\
\hline Arizona & 1 year & Manual, classes & General ID, land. design & 70 & ANA & 3 years \\
\hline Arkansas & 1 year or hort. deg. & Manual, classes & General ID, land. design & 75 & ANA & 3 years \\
\hline California & $\begin{array}{l}18 \text { months } \\
\text { or } 3120 \mathrm{~h}\end{array}$ & Manual, classes & General ID, land. design & 70 & CAN & 2 years \\
\hline Colorado & 2 years or $4000 \mathrm{~h}$ & Manual & General ID, land. design & 75 & CNA & 3 years \\
\hline Connccticut & $\begin{array}{l}\text { Employed by } \\
\text { nursery }\end{array}$ & Manual, classes & General & 70 & CNA & Lifetime \\
\hline Delaware & $\begin{array}{l}3 \text { years or } 2 \text { years }+ \\
2 \text {-year hort. deg. } \\
\text { or } 1 \text { year }+4 \text {-year } \\
\text { hort. deg. }\end{array}$ & Manual, classes & $\begin{array}{l}\text { Core exam, one to six } \\
\text { specialty exams }\end{array}$ & 75 & $\mathrm{DAN}$ & 3 years \\
\hline Florida & 90 days & Manual, classes, ID & General ID & 70 & FNGA & 3 years \\
\hline Georgia & 6 months (negot.) & Manual, classes & General ID & 70 & GNA & Lifetime \\
\hline Illinois & $\begin{array}{l}4000 \mathrm{~h} \text { or } 2000 \mathrm{~h} \\
+2 \text { years college }\end{array}$ & Manual & General ID & 70 & INA & 3 years \\
\hline Indiana & None & Manual, classes & General & 80 & INA & Lifetime \\
\hline Iowa & I year & Manual, classes & General ID, land. design & 75 & INA & Annually \\
\hline Kansas & $\begin{array}{l}6 \text { months or } \\
1 \text { year part }\end{array}$ & Manual, classes & General ID, land. design & 80 & KAN & Annually \\
\hline Kentucky & $\begin{array}{l}6 \text { months or } \\
500 \mathrm{~h} \text { part }\end{array}$ & Manual & General ID, land. design & 70 & KNA & Lifetime \\
\hline Louisiana & None & Manual, classes & General ID & 70 & LAN & Lifetime \\
\hline Maine & $\begin{array}{l}2 \text { years or } 1 \text { work } \\
\text { year }+1 \text { year of } \\
\text { college }\end{array}$ & Manual, classes & General & 70 & MNA & 3 years \\
\hline Maryland & $\begin{array}{c}3 \text { years or } 2 \text { years }+ \\
2 \text { years of college }\end{array}$ & Manual & General ID & 70 & MNA & 3 years \\
\hline Massachusetts & $\begin{array}{c}3 \text { years or } 2 \text { years }+ \\
2 \text { years of college }\end{array}$ & Manual, classes & General ID & 70 & MNA & 3 years \\
\hline Michigan & 1 year & Manual, classes & General ID, land. design & 70 & MNLA & Annually \\
\hline Minnesota & $\begin{array}{l}2000 \mathrm{~h} \text { or } 1 \text { year of } \\
\text { college with } \\
\text { internship }\end{array}$ & Manual & General ID, land. design & 75 & MNLA, $U$ of $M$ & 3 years \\
\hline Mississippi & 6 months & Manual, classes & General ID & 80 & MNA, MSU & Lifetime \\
\hline Missouri & $\begin{array}{l}1 \text { year or } \\
1000 \mathrm{~h} \text { part }\end{array}$ & Manual, classes & General ID, land. design & 60 & MAN & Annually \\
\hline \multicolumn{7}{|c|}{ Montana (uses Idaho's system) } \\
\hline New Jersey & $2080 \mathrm{~h}$ & Manual, classes & General ID & 70 & NJN\&LA & Annually \\
\hline New Mexico & 2 years or hort. deg. & Manual, classes & General ID, land. design & 70 & NMANI, NMSU & 3 ycars \\
\hline New York & 1 year & Manual, classes & General ID & 75 & NYNLA & 5 years \\
\hline North Carolina & 1 year & Manual, classes & General ID & 70 & NCAN & Lifetime \\
\hline Ohio & $\begin{array}{l}6 \text { months or } \\
5000 \text { h part }\end{array}$ & Manual, classes & General ID & 72 & ONA & 3 ycars \\
\hline Oklahoma & 1 year & Manual & General ID, land. design & 70 & OSNA & 3 years \\
\hline Oregon & 1 year & Manual & General ID, land. design & 70 & OAN & 3 years \\
\hline Pennsylvania & $\begin{array}{l}2 \text { years or } 2- \\
\text { year hort. deg. }\end{array}$ & $\begin{array}{l}\text { Manual, exam syllabus } \\
\text { sample exam }\end{array}$ & General, land. design & 80 & PNA & Lifetime \\
\hline Rhode Island & $\begin{array}{l}3 \text { years or } 2 \text { years } \\
\text { work }+2 \text { years } \\
\text { college }\end{array}$ & Manual, classes & General ID, land. design & 80 & RINA & 3 years \\
\hline South Carolina & None & Manual, classes & General ID & 80 & SCNA, CU & Lifetime \\
\hline Tennessee & 90 days & Manual, classes & General ID & 70 & TAN & 3 years \\
\hline Texas & $\begin{array}{c}6 \text { months or } \\
500 \mathrm{~h} \text { part }\end{array}$ & Manual, classes & General ID & 70 & TAN & Annually \\
\hline Utah & $\begin{array}{l}1 \text { year or } 1 \text { year } \\
\text { of college }\end{array}$ & Manual, classes & General ID, land. design & 90 & UANLC & 5 years \\
\hline Vermont & 3 years & Manual, classes & General ID & 70 & VPA & Lifetime \\
\hline Virginia & None & Manual, classes & General & 75 & VNA & Lifetime \\
\hline Washington & 1 year & Manual, classes & General ID, land. design & 70 & WSNLA & $\begin{array}{l}3 \text { years, then life- } \\
\text { time }\end{array}$ \\
\hline
\end{tabular}

${ }^{z}$ Hours, months, and years listed denote actual work experience required unless otherwise indicated by part-time work substitution and/or partial or full waiver with years of college or degree.

"The average score necessary to pass each section of the certification examination. A higher overall average may be required by some states.

${ }^{x}$ The time before recertification is required. Fees, however, may be required at more regular intervals for some state associations.

Note: The majority of nursery organizations allow for flexibility or deviation from the above standards on a case-by-case basis.

Maintaining eligibility. Most states do not grant lifetime certification status. Many states that currently offer lifetime status plan to eventually implement a recertification policy. To encourage ongoing education of a certified individual, most states require recertification every 3 to 4 years. Ongoing certification fees, however, often are re- quired yearly before recertification is required. Recertification classes are offered by both industry leaders and university personnel in most states. Examinations rarely are retaken if the employee attends the required number of continuing education units (CEUs), short courses, or obtains points that often are offered at trade shows or annual 
nursery conventions. In addition, a recertification fee must be paid. Inmost cases, if the individual fails to recertify by the deadline, the original process, including the full examination, must be repeated.

Certification administration. State certification programs are administered by a variety ofmethods. The nursery association s executive director normally supervises a certification committee that includes key industry members and university representatives. A list of organizations administering certification programs is given in Table 2 .

Future of certification programs. All state organizations that have pursued the initiation of certified nursery personnel programs have found them to be beneficial to all involved. Although time-consuming to the certification committee, manuals and overall certification programs are updated constantly to help the nursery employee stay abreast of new developments in ornamental horticulture and its allied fields. A comparison of the states certification programs is outlined in Table 3. Many states have modified neighboring states certification programs to satisfy unique situations in their area. In future programs, it may be advantageous for state nursery organizations to coalesce, and perhaps standardize, certification procedures across geographical regions within the United States. The infrastructure to implement this already exists with regional organizations such as the Southern Nurserymen s Assn., Eastern Regional Nurserymen s Assn., Western Assn. of Nurserymen, and the New England Nurserymen s Assn. 